ISSN 1412-2936

EISSN 2549-7308

\title{
PENGARUH MOTIVASI INTRINSIK DAN EKTRINSIK TERHADAP KINERJA KADER POSYANDU
}

(Study Kasus di Wilayah Kerja Puskesmas Kecamatan Cidahu

Kabupaten Kuningan)

Dhea Perdana Coenraad ${ }^{1}$, Haris Nurdiansyah ${ }^{2}, \mathrm{U}$ Wawan Sam Adinata ${ }^{3}$, STIE Pasundan Bandung ${ }^{123}$

Email :aradhea.virus1988@gmail.com ${ }^{1}$

Email : haris.stiepasundan@gmail.com²

Email :humas.stiepas@gmail.com ${ }^{3}$

\begin{abstract}
ABSTRAK
Tujuan penelitian ini adalah untuk mengetahui pengaruh motivasi intrinsik dan ekstrinsik terhadap kinerja kader posyandu di Kecamatan Cidahu Kabupaten Kuningan. Kinerja merupakan hal yang sangat penting dalam setiap aktifitas organisasi terutama dalam hal mencapai tujuan organisasi itu sendiri. Rendahnya kinerja sangat erat hubungannya dengan individu masing-masing diantaranya adalah faktor motivasi dalam setiap individu tersebut. Dalam membentuk kinerja yang optimal perlu ada dorongan dalam diri sendiri dan juga dorongan dari luar oleh karena itulah motivasi dalam diri atau intrinsik dan motivasi ekstrinsik dibutuhkan dalam mencapai kinerja yang prima.
\end{abstract}

Keyword : Kinerja, Motivasi Intrinsik dan Motivasi Ekstrinsik

ABSTRACT
The purpose of this study was to determine the effect of intrinsic and extrinsic motivation on the performance of posyandu cadres in Cidahu District, Kuningan District. Performance is very important in every activity of the organization, especially in terms of achieving the goals of the organization itself. The low performance is very closely related to each individual including the motivational factor in each individual. In shaping an optimal performance there needs to be encouragement within oneself and also encouragement from the outside because that is inner motivation or intrinsic and extrinsic motivation is needed in achieving excellent performance.

\section{Keyword: Performance, Intrinsic Motivation and Extrinsic Motivation}

\section{Pendahuluan}

Kesehatan merupakan sesuatu hal yang sangat penting dalam kehidupann bermasyarakat sehingga permasalahan akan kesehatan tidak terlepas dari berbagai elemen yang mendukungnya diantaranya adalah posyandu, dimana posyandu merupakan central utama kesehatan masyarakat khususnya di daerah-daerah yang masih minim fasilitas kesehatan.Masalah kesehatan ibu dan anak merupakan salah satu masalah dari sekian masalah yang ada atau sering muncul dalam kehidupan bermasyarakat, oleh karena itu dengan adanya kondisi seperti ini maka tingkat kesehatan masyarakat/derajat kesehatan masih belum optimal karena menurut berbagai sumber banyak sekali kendala dalam pelayanan kesehatan sehingga dapat berjalan optimal dan memenuhi kebutuhan masyarakat itu sendiri. Dalam rangka mencapai derajat kesehatan masyarakat yang optimal, pembangunan kesehatan harus diarahkan untuk meningkatkan kesadaran, kemauan, dan kemampuan hidup sehat bagi setiap orang (Kemenkes RI, 2010). 
Sumberdaya manusia yang sehat dan berkualitas, merupakan modal utama atauinvestasi dalam pembangunan kesehatan, Indeks Pembangunan Manusia (IPM) Indonesia Tahun 2002 menduduki peringkat111 dari 175 negara didunia,dan merupakan yang terendah di antara negara- negara kawasan Asia Tenggara (Depkes RI,2006, p.1).

Masyarakat memiliki peran penting untuk mencapai keberhasilan dalam setiap pembangunan, termasuk pembangunan di bidang kesehatan. Konsep Pembangunan kesehatan bertujuan untuk meningkatkan kesadaran, kemauan, dan kemampuan hidup sehat bagi setiap orang agar terwujud derajat kesehatan masyarakat yang setinggi-tingginya,sebagai investasi bagi pembangunan sumberdaya manusia yang produktif secara sosial dan ekonomis (UU Kes Rl,2009, Pasal.3), artinya bahwa setiap anggota masyarakat, baik individu, keluarga ataupun kelompok, secara bersamasama bertanggung jawab dalam mengembangkan kemandirian, menggerakkan, dan melaksanakan upaya kesehatan. Bentuk dari peran serta dan tanggung jawab masyarakat dalam pelaksanaan pembangunan bidang kesehatan adalah pemberdayaan sebagaimana tercantum dalam Keputusan Menteri Kesehatan Republik Indonesia Nomor 374/Menkes/SKN/2009 tentang Sistem Kesehatan Nasional (SKN) dimana pemberdayaan merupakan salah satu subsistem dari SKN. Kebijakan ini dilaksanakan oleh pemerintah daerah Provinsi Jawa Barat dalam bentuk upaya kesehatan bersumber daya masyarakat (UKBM) yang salah satu contohnya adalah posyandu.

Posyandu merupakan salah satu bentuk UKBM yang dikelola dan diselenggarakan dari, oleh, untuk dan bersama masyarakat dalam penyelenggaraan pembangunan kesehatan guna memberdayakan masyarakat dan memberikan kemudahan kepada masyarakat dalam memperoleh pelayanan kesehatan dasar. Pelaksanaan kegiatan posyandu terdiri dari kegiatan utama dan kegiatan pengembangan / pilihan, kegiatan utama, mencakup; kesehatan ibu dan anak, keluarga berencana, imunisasi, gizi, pencegahan dan penanggulangan diare. (Kemenkes, 2012, p.3).

Kegiatan posyandu merupakan ujung tombak pelayanan kesehatan yang bersumber dari, oleh, dan untuk masyarakat dalam rangka menunjang penyelesaian permasalahan kesehatanibu dan anak khususnya, serta masalah kualitas hidup masyarakat seperti gizi buruk anak balita, kekurangan gizi, busung lapar, dan masalah kesehatan lainnya. Upaya yang dilakukan baik yang bersifat pencegahan (preventif) maupun pengobatan dasar merupakan bagian penting dari kegiatan posyandu itu sendiri yang merupakan tempat atau media yang paling dekat dengan masyarakat dalam pemantauan gizi pada balita, sehingga masyarakat secara langsung dapat memantau pertumbuhan dan perkembangan status gizi balitanya. Dalam rangka menurunkan angka kematian anak maka dilakukan pengembangan upaya kesehatan bersumber masyarakat sepertiposyandu dengan melalui penanggulangan kurang energi protein, pendidikan gizi, penyediaan sarana air bersih dan sanitasi dasar, serta pencegahan dan pemberantasan penyakit. Semua kegiatan yang dilaksanakan pada kegiatan posyandu sangat bergantung pada peran kader, kader-kader inilah yang mempunyai andil cukup besar dalam proses kelancaran pelayanan kesehatan, namun keberadaan kader masih relatif labil karena bersifat sukarela karena tidak mendapat gaji, sehingga tidak ada jaminan bahwa kader akan menjalankan fungsinya dengan baik seperti yang diharapkan. Jika ada kepentingan keluarga ataupun kepentingan lain maka posyandu ditinggalkan (Yudiansyah, 2008).

Kader adalah seorang tenaga sukarela yang direkrut dari, oleh dan untuk masyarakat, yang bertugas 
membantu kelancaran pelayanan kesehatan. Keberadaan kader sering dikaitkan dengan pelayanan rutin posyandu, sehingga seorang kader posyandu harus mau bekerja secara sukarela dan ikhlas. Mau dan sanggup melaksanakan dan mengikuti kegiatan posyandu (Cahyo Ismawati S., dkk, 2010). Kader Posyandu yang selanjutnya disebut kader adalah anggota masyarakat yang bersedia, mampu dan memiliki waktu untuk menyelenggarakan kegiatan Posyandu secara sukarela (Kemenkes RI, 2011). Pada saat penyelenggaraan Posyandu minimal jumlah kader adalah 5 orang. Kader memiliki tugas yang dibagi 3 yaitu sebelum hari buka Posyandu, saat hari buka Posyandu, dan diluar hari buka Posyandu. Peran kader sangat menentukan keberhasilan kegiatan Posyandu, dengan berperan dalam pembinaan masyarakat di bidang kesehatan melalui kegiatan yang dilakukan di posyandu, sehingga kader harus mempunyai pengetahuan tentang perannya untuk melaksanakan program-program untuk kelangsungan pelayanan di posyandu sesuai dengan situasi atau kebutuhan dasar yang dalam kegiatannya tetap memperhatikan aspek pemberdayaan masyarakat. Salah satu faktor yang mempengaruhi peran kader adalah motivasi kader kesehatan itu sendiri (Depkes RI, 2006).

Peran kader dalam program kesehatan ibu dan anak adalah untuk mengkonfirmasikan segala permasalahan kesehatan yang berhubungan dengan kesehatan ibu hamil, bayi baru lahir serta mampu menjadi penggerak bagi kelompok atau organisasi masyarakat yang ada. Salah satu fungsi kader dalam kesehatan ibu dan anak adalah membantu tenaga kesehatan ibu dan anak adalah membantu tenaga kesehatan untuk mengenal dan menemukan ibu hamil yang beresiko dengan melakukan kunjungan rumah (Cahyo, 2010).

Menurut Dijen Binakesmas Depkes RI (2009) bahwa kinerja posyandu mengalami penurunan, hal tersebut diketahui dari cakupan balita yang datang ke posyandu turun dari $60 \%$ menjadi $43 \%$ sehingga, banyak ditemukan balita yang tidak ditimbang dan tidak mendapat immunisasi yang mengakibatkan semakin meningkatnya prevalensi gizi kurang yang dapat berlanjut menjadi gizi buruk. Keterbatasan petugas yang mempunyai fungsi rangkap dalam melakukan tugasnya dipuskesmas mengakibatkan tidak semuanya kegiatan pelaksanaan program kesehatan bisa dilakukan dengan optimal, hal ini juga tidak terkecuali terkait dengan penanganan gizi masyarakat, sehingga berkenaan dengan pelacakan gizi buruk tidak dapat terdeteksi sedini mungkin, sehingga balita ditemukan sudah dalam kondisi yang tidak baik. Untuk itu puskesmas sangat memerlukan partisipasi para kader dalam membantu saat kegiatan posyandu dan juga diluar kegiatan posyandu, karena para kader dapat membantu petugas puskesmas dalam mendeteksi secara dini berkenaan dengan gizi masyarkat sehingga penemukan kondisi balita yang berat badannya tidak naik setiap bulannya dan tidak datang ke posyandu akan segera terlaporkan untuk menjadi dasar penanggulangan petugas kesehatan dalam melakukan penanggukangannya.

Permasalahan yang sama dialami oleh posyandu di kabupaten Kuningan, yaitu salah satu kabupaten yang mempunyai rasio posyandu/desa terendah di Jawa Barat sebanyak3,51 atau 3 sampai 4 posyandu/desa/kecamatan. Jumlah posyandu masih jauh dari target yang diharapkan yaitu 1.761 posyandu untuk 176.142 balita yang ada di kabupaten kuningan (Dinkes Kab. Kuningan : 2018) dan dari tahun ke tahun jumlahnya makin menurun dari 1.346 pada tahun 2017 menjadi1.315 posyandu pada tahun 2018. Selain jumlah posyandu, kader merupakan kunci utama dalam kegiatan posyandu mulai dari perencanaan, pelaksanaan termasuk pencatatan, dan pelaporan. Kader sebagai salah satu sub system dalam posyandu yang bertugas 
untuk mengatur jalannya program dalam posyandu, kader harus lebih tahu atau lebih menguasai tentang kegiatan yang harus dijalankan atau dilaksanakan. Kemampuan kader yang lebih serta keaktifan yang tinggi, akan mempengaruhi kondisi dan keadaan sebuah posyandu begitu juga sebaliknya keaktifan kader yang rendah akan menurunkan aktivitas sebuah organisasi. Keaktifan kerja kader akan memperlihatkan sejauh mana peran posyandu yang ada disuatu komunitas.

Berkenaan dengan penurunan kinerja kader posyandu ini dibuktikan dengan penelitian Mastuti (2003) terhadap kaderposyandu di Kecamatan Panjatan Kabupaten Kulon Progo Propinsi Daerah Istimewa Yogyakarta pada Bulan Maret Tahun2003, bahwa persentase kader aktif nasional adalah $69,2 \%$ dan persentase kader drop out sebesar 30,8\%. Menurut Syafridah (2003) bahwa kader yang drop out adalah sebagai tulang punggung keluarga, dan Berdasarkan studi terdahulunya bahwa angka drop outkader sangat tinggi atau rata-rata $50 \%$, penyebab utamanya karena tidak adanya sistim penghargaan bagi kader. Sedangkan menurut Monteiro,dkk (2009) menyatakan bahwa kader muda yang masih dalam usia pencari kerja lebih tinggi drop outnya dibanding kader yang sudah tua.

Terjadinya penurunan kinerja kader ini sangat di pengaruhi sekali oleh motivasi kader kesehatan dalam menjalankan peran dan fungsinya untuk melaksanakan kegiatan posyandu yang optimal serta pelayanan kesehatan dasar lainnya seperti penyuluhan, monitoring dan pemantaunan terhadap sasaran, hal ini sesuai dengan penelitian yang dilakukan oleh Henni Djuhaeni et. al (2010) dengan hasil studinya tentang motivasi kader meningkatkan keberhasilan kegiatan posyandu menyimpulkan bahwa Hasil penelitian memperlihatkan bahwa faktor motivasi berpengaruh terhadap peran serta kader dan masyarakat dalam posyandu. Meskipun demikian terdapat berbagai variasi pengaruh. Pada kader tidak aktif terjadi hal sebaliknya, sedangkan pada masyarakat, kedua faktor motivasi menunjukkan pengaruh yang tidak bermakna. Simpulan, pengaruh dan perbedaan pengaruh motivasi terhadap peran serta kader dan masyarakat menentukan keberhasilan kegiatan posyandu. Selain itu penelitian lain yang dilakukan Meria Kontesa (2013), Hasil penelitian menunjukkan bahwa lebih dari separuh $(60,6 \%)$ responden di wilayah kerja Puskesmas Air Dingin kecamatan koto tangah kota Padang memiliki motivasi kerja yang rendah. Hasil tersebut sejalan dengan fenomena rendahnya motivasi kerja kader posyandu, rendahnya motivsi kerja tersebut tentu akan berpengaruh negatif terhadap kinerja kader dalam menjalankan posyandu.

Menurut Basyir, dkk (2008) bahwa faktor ekstrinsik merupakan faktor pendukung dalam meningkatkan keaktifan kader posyandu. Faktor ekstrinsik dalam kegiatan posyandu yang berupa fasilitas posyandu dan sarana pendukung dapat meningkatkan keaktifan kader dalam melaksanakan kegiatan posyandu. Pemberdayaan kader melalui pelatihan, penyegaran, dan cerdas cermat, serta pengadaan alat masak dan kebutuhan operasional, supaya kader posyandu dapat meningkatkan kinerja dan fungsi sehingga mampu mengemban tugasnya untuk meningkatkan gizi keluarga. Insentif yang diberikan kepada kader, adanya kemudahan bagi kader dalam pegobatan di puskesmas juga memberikan motivasi tersendiri bagi keaktifan kader posyandu. Hal ini juga sesuai dengan penelitian Muntasir, Sinaga, Nesi dan Nabuasa (2009), tingkat motivasi kader sangat mempengaruhi prestasi kerjanya, sebagian besar $(72,24 \%)$ mempunyai tingkat motivasi sedang. Sedangkan berdasarkan peran sertanya dalam pelaksanaan kegiatan posyandu pada umumnya kader aktif dengan tingkat motivasi tinggi. Berarti semakin tinggi tingkat motivasi seorang kader semakin 
aktif pula dalam pelaksanaan kegiatan posyandu. Berdasarkan penelitianpenelitian sebelumnya yang sudah dilakukan penulis mendasari bahwa penelitian sebelumnya lebih terfokus pada pengaruh motivasi secara umum terhadap kinerja dalam penelitian ini penulis mencoba melakukan pembaharuan dengan melakukan penelitian yang didasari pada variable motivasi secara khusus yaitu motivasi intrinsic dan ekstrinsik.

\section{Tinjauan Pustaka \\ Sumber Daya Manusia}

Berikut ini sejumlah pengertian manajemen sdm menurut beberapa pakar yang sudah terpublikasi secara umum:

Wayne Mondy (Wayne Mondy, 2008:4) mengartikan manajemen sumber daya manusia sebagai berikut: "Manajemen sumber daya manusia adalah pemanfaatan sejumlah individu untuk mencapai tujuan-tujuan organisasi".

Menurut Gary Dessler (Dessler, 2003:2): "Human Resource Management is the policies and practies involved in carrying out the "people" or human resource aspects of a management position, including recruiting, screening, training, rewarding, and appraising."

(artinya manajemen SDM adalah kebijakan dan cara-cara yang dipraktekan dan berhubungan dengan pemberdayaan manusia atau aspekaspek SDM dari sebuah posisi manajemen termasuk perekrutan, seleksi, pelatihan, penghargaan dan penilaian.)

Di samping itu, menurut T.Hani Handoko (Handoko, 2015:4):"Manajemen sumber daya manusia adalah penarikan, seleksi, pengembangan, pemeliharaan, dan penggunaan sumber daya manusia untuk mencapai baik tujuan-tujuan individu maupun organisasi."

Dari berbagai derfinisi diatas bahwa dapat disimpulkan bahwa manajemen sumber daya manusia merupakan suatu kegiatan atau kumpulan orang-orang yang melakukan berbagai aktivitas didalamnya mulai dari seleksi hingga pemutusan hubungan kerja didalam suatu organisasi dengan tujuan mencapai visi dan misi yang telah ditetapkan oleh organisasi tersebut.

\section{Motivasi Intrinsik}

Motivasi intrinsik adalah motivasi yang mendorong seseorang untuk berprestasi yang bersumber dalam diri individu tersebut, yang lebih dikenal dengan faktor motivasional. Menurut Herzberg yang dikutip oleh Luthans (2011: 160 ), yang tergolong sebagai faktor motivasional antara lain ialah:

\section{a. Achievement (Keberhasilan)} yaitu Prestasi seorang karyawan dapat dilihat dari prestasi kerja yang diraihnya. Agar sesorang karyawan dapat berhasil dalam melakasanakan pekerjaannya, maka pemimpin harus memberikan dorongan dan peluang agar bawahan dapat meraih prestasi kerja yang baik. Ketika seorang bawahan memiliki prestasi kerja yang baik maka atasan harus memberikan penghargaan atas prestasi yang dicapai bawahan tersebut.

b. Recognition

(pengakuan/penghargaan)

Sebagai lanjutan dari keberhasilan pelaksanaan, pimpinan harus memberi pernyataan pengakuan terhadap keberhasilan bawahan dapat dilakukan dengan berbagai cara yaitu:

c. Work it self (Pekerjaan itu sendiri) Pimpinan harus membuat kondisi dimana bawahan mengerti akan pentingnya pekerjaan yang dilakukannya dan membuat bawahan menghindari kebosanan rutinitas pekerjaan dengan berbagai macam cara, serta dapat menempatkan orang yang tepat di waktu yang tepat.

d. Responsibility (Tanggung jawab) 


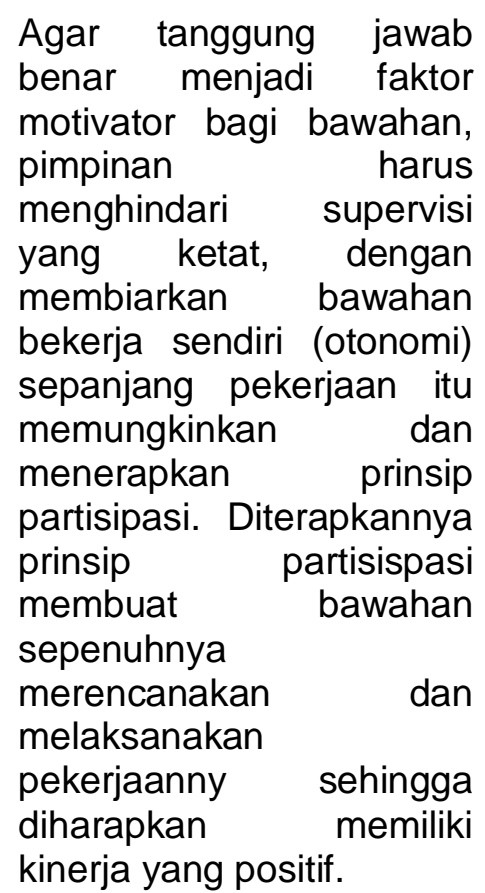

e. Advencement (Pengembangan) Pengembangan

merupakan salah satu faktor motivasi bagi bawahan. Faktor pengembangan ini benarbenar berfungsi sebagai motivator, maka pemimpin dapat memulainya dengan melatih bawahannya untuk pekerjaan yang lebih bertanggung jawab. Bila hal tersebut sudah dilakukan, pemimpin dapat memberi rekomendasi tentang bawahan yang siap untuk pengembangan, pengembangan dapat dilakukan dengan cara mengirim karyawan untuk melakukan pelatihan dan promosi kenaikan jabatan.

\section{Motivasi Ekstrinsik}

Motivasi Ekstrinsik adalah motivasi yang bersumber dari luar diri yang turut menentukan perilaku seseorang dalam kehidupan seseorang yang dikenal dengan teori hygiene factor. Menurut Herzberg yang dikutip oleh Luthans (2011 : 160 ), yang tergolong sebagai hygiene factor antara lain ialah sebagai berikut:

a. Quality supervisor (Supervisi)

Supervisi adalah melakukan pengamatan secara langsung dan berkala oleh atasan terhadap pekerjaan yang dilaksanakan oleh bawahan untuk kemudian apabila ditemukan masalah, segera diberikan petunjuk atau bantuan yang bersifat langsung. Kualitas supervisi mempengaruhi motivasi karyawan, dengan kualitas supervisi yang baik dan fleksibel maka karyawan akan merasa nyaman dan dapat memberikan kinerja yang maksimal.

b. Interpersonal relation (Hubungan Interpersonal relation menunjukkan hubungan perseorangan antara bawahan dengan atasannya, dimana kemungkinan bawahan merasa tidak dapat bergaul dengan atasannya. Agar tidak menimbulkan kekecewaaan karyawan, maka minimal ada tiga kecakapan harus dimiliki setiap atasan yakni:

1) Technical skill (kecakapan terknis).

Kecakapan ini sangat penting bagi pimpinan, kecakapan ini meliputi penggunaan metode dan proses komunikasi yang pada umumnya berhubungan dengan kemampuan menggunakan alat.

1) Human skill (kecakapan konsektual)

Adalah kemampuan untuk bekerja didalam atau dengan kelompok, sehingga dapat membangun kerjasama dan mengkoordinasikan berbagai kegiatan.

2) Conseptual skill (kecakapan konseptual)

Adalah kemampuan memahami kerumitan organisasi sehingga dalam berbagai tindakan yang diambil dibawah tekanan selalu dalam usaha untuk merealisasikan tujuan organisasi secara keseluruhan.

c. Working condition (Kondisi kerja) 
Menurut Hezberg seandainya kondisi lingkungan yang baik dapat tercipta, prestasi yang tinggi dapat tercipta, prestasi tinggi dapat dihasilkan melalui kosentrasi pada kebutuhan-kebutuhan atas ego dan perwujudan diri yang lebih tinggi. Kondisi lingkungan kerja yang baik dan nyaman akan dapat meningkatkan motivasi kerja pada karyawan dibandingkan dengan kondisi kerja yang penuh tekanan dan inferior.

d. Wages (Gaji)

Gaji merupakan salah satu unsur penting yang memiliki pengaruh besar terhadap motivasi karyawan. Oleh karena itu perusahaan harus berhati-hati dalam melakukan kebijakan masalah gaji agar dapat meningkatkan kinerja karyawan.

\section{Pengaruh Motivasi Intrinsik Terhadap Kinerja Kader}

Hasil kerja karena kesadaran menciptakan kinerja yang baik dan karyawan akan sadar bahwa dengan memiliki kinerja yang baik, ia akan dapat memenuhi kebutuhan hidupnya. Hal ini sesuai dengan penelitian yang dilakukan oleh Febrian Nurtaneo Akbar (2013) yang menunjukkan adanya pengaruh yang signifikan antara motivasi intrinsik terhadap kinerja karyawan. Priansa (2014) menyatakan bahwa motivasi intrinsic merupakan salah satu faktor utama dalam menentukan kinerja seseorang.

\section{Pengaruh Motivasi Ektrinsik Terhadap Kinerja}

Kinerja merupakan hal yang perlu dikelola diantaranya dengan melakukan pengelolaan terhadap motivasi ekstrinsik seseorang sehingga dapat mencapai kinerja yang optimal. Kusdiyah (2014) menyatakan bahwa kinerja yang optimal tidak lahir dengan sendirinya namun perlu ada upaya untuk mencapainya dianataranya adalah dengan memberikan motivasi ektrinsik seperti penghargaan bagi seorang pegawai.

\section{Metode Penelitian}

\section{Waktu Dan Tempat Penelitian}

Lokasi penelitian dilakukan di Kecamatan Cidahu Kabupaten Kuningan Tahun 2019

\section{Populasi dan Data Penelitian}

Populasi data yang digunakan adalah Kader Posyandu yang berjumlah 72 orang responden.

\section{Operasionalisasi Variabel}

Variabel dalam penelitian ini terdiri dari 2 (dua) macam variabel, yaitu variabel bebas dan variabel terikat. Menurut Sugiyono (2012:39)Variabel bebas adalah variabel yang mempengaruhi atau yang menjadi sebab perubahannya atau timbulnya variabel dependen atau variabel terikat, sedangkan variabel terikat adalah variabel yang dipengaruhi atau menjadi akibat, karena adanya variabel bebas.

Variabel bebas dalam penelitian ini adalah Motivasi intrinsik (X1) dan Motivasi ekstrinsik (X2), sedangkan yang menjadi variabel terikatnya adalah variabel kinerja (Y). Agar variabelvariabel tersebut dapat diukur secara kuantitatif, maka harus dioperasionalkan sebagai berikut :

\section{Operasionalisasi Variabel}

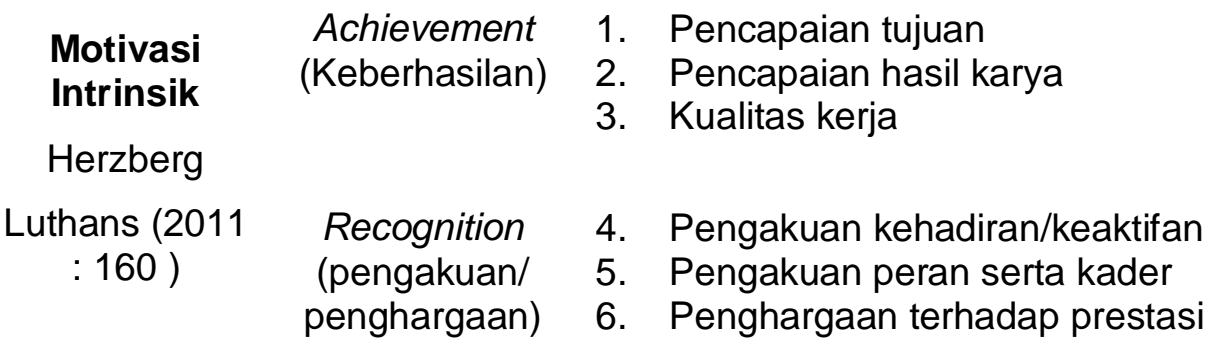


ISSN 1412-2936

EISSN 2549-7308

\author{
Work it self 7. Semangat kerja \\ (Pekerjaan itu 8. Beban Pekerjaan \\ sendiri) 9. Pelayanan masyarakat \\ 10. Tantangan kerja \\ Responsibility 11. Pekerjaan tepat waktu. \\ (Tanggung jawab) 12. Kemampuan dalam mengerjakan \\ pekerjaan \\ 13. Kekuatan menanggung pekerjaan.
}

Advencement 14. Peningkatan kapasitas kader.

(Pengembang 15. Keterbukaan akan peningkatan setiap an) kader.

16. Peluang dalam peningkatan kapasitas.
Motivasi
Quality supervisor 17. Pembinaan petugas kesehatan
Ektrinsik
(Supervisi)
18. Kerjasama tim
19. Perhatian Pemerintahan desa
Herzberg
20. Peran serta tokoh masyarakat

Luthans (2011

: 160 )
Interpersonal
21. Hubungan antar kader relation (Hubungan
22. Hubungan dengan petugas
antar pribadi) kesehatan/bidan desa.
23. Komunikasi dan koordinasi dengan desa.
Working condition 24. Ketersediaan sarana prasarana
(Kondisi kerja) posyandu
25. Lingkungan posyandu.
26. Penataan ruangan posyandu
Wages 27. Insentif kader
(Insentif) 28. Bonus/tambahan imbalan

$\begin{array}{lll}\begin{array}{l}\text { Kinerja } \\ \text { Kader }\end{array} & \text { Kehadiran } & \text { 29. Mengunjungi sasaran posyandu } \\ \text { 30. Hadir tepat waktu pada saat posyandu } & & \\ \text { Telaah } & & \\ \text { kemandirian } & & \\ \text { posyandu } & & \\ \text { dalam buku } & \text { Keterlibatan dalam } & \text { 31. Persiapan pra posyandu } \\ \text { pedoman } & \text { Kelayanan pelaksanaan posyandu } \\ \text { ARRIF } & \text { kegiatan posyandu } & \text { 32. Pelayanan diluar/pasca posyandu } \\ \text { (Depkes, } & & \end{array}$

\title{
Teknik Analisis Data
}

Penelitian ini menggunakan dua metode analisa data yaitu analisa regresi (Anreg) dan analisa varian (Anova). Anreg digunakan untuk mengetahui motivasi intriksi dan motivasi ektrinsik dengan variabel terkait yaitu Kinerja Kader Posyandu. Sedangkan Anava digunakan untuk mengetahui mana diantara variabel bebas yaitu perbandingan antara motivasi intrinsik 
dan motivasi ekstrinsik dengan Kinerja Kader Posyandu.

berikut:

$$
\text { Rumus regresi sebagai }
$$

$$
\bar{Y}=b_{0}+b_{1} X_{1}+b_{2} X_{2}+e
$$

Keterangan :

$\bar{Y}=$ Nilai taksiran y $b_{0}=$ Nilai y pada perpotongan antara garis linier dengan sumbu vertikal y

$X_{I}=$ Motivasi intrinksik

$\mathrm{X}_{2}=$ Motivasi ektrinsik

Setelah diketahui mana dari varibel bebas yang berpengaruh pada kinerja kader posyandu maka dilakukan analisas varian. Melalui analisa varian ini bisa diketahui perbandingan internal dan motivasi ekternal dengan produktivitas kerja. Analisa varian termasuk dalam analisa kompratif. Fungsinya adalah untuk menguji apakah perbedaan rerata antar kelompok yang satu dengan kelompok yang lainnya signifikan apa tidak. Dalam hal ini akan dilakukan Uji T yang merupakan uji berpasangan yaitu uji perbedaan rerata antara dua kelompok.

\section{Hasil dan Pembahasan}

Analisis Regresi Linier Berganda

\begin{tabular}{|c|c|c|c|c|c|c|c|c|c|}
\hline \multirow{2}{*}{\multicolumn{2}{|c|}{ Model }} & \multicolumn{2}{|c|}{$\begin{array}{c}\text { Unstandardized } \\
\text { Coefficients }\end{array}$} & \multirow{2}{*}{\begin{tabular}{|c|}
$\begin{array}{c}\text { Standardiz } \\
\text { ed } \\
\text { Coefficient } \\
\text { s }\end{array}$ \\
Beta
\end{tabular}} & \multirow[t]{2}{*}{$t$} & \multirow[t]{2}{*}{ Sig. } & \multicolumn{3}{|c|}{ Correlations } \\
\hline & & $B$ & $\begin{array}{l}\text { Std. } \\
\text { Error }\end{array}$ & & & & $\begin{array}{l}\text { Zero- } \\
\text { order }\end{array}$ & $\begin{array}{c}\text { Partia } \\
1\end{array}$ & Part \\
\hline \multirow{3}{*}{1} & (Constant) & 6.849 & 2.991 & & 2.290 & .025 & & & \\
\hline & $\begin{array}{l}\text { Motivasi } \\
\text { Intrinsik }\end{array}$ & .257 & .037 & .568 & 6.929 & .000 & .724 & .641 & .511 \\
\hline & $\begin{array}{l}\text { Motivasi } \\
\text { Ekstrinsik }\end{array}$ & .227 & .052 & .354 & 4.317 & .000 & .603 & .461 & .318 \\
\hline
\end{tabular}

Tabel 1 Analisis Regresi Linier Berganda

a. Dependent Variable: Kinerja Kader

Berdasarkan hasil pengolahan data seperti disajikan pada tabel diatas maka dapat dibentuk persamaan regresi variabel masa kerja dan promosi terhadap kinerja sebagai berikut.

$\mathrm{Y}=6.849+0,257 \mathrm{X}_{1}+0.227 \mathrm{X}_{2}$

Artinya dapat dijelaskan bahwa jika pada kondisi $\mathrm{x}=0$ maka $\mathrm{y}$ sebesar 6.849 atau bila tanpa motivasi intrinsik dan ekstrinsik maka kinerja kader sebesar $Y$ sedangkan jika motivasi intrinsik kader ditingkatkan 1 satuan maka akan meningkatkan kinerja kader sebesar 0,257 $X$ dan jika motivasi ekstrinsik ditingkatkan maka akan meningkatkan kinerja kader sebesar $0,227 \mathrm{X}$. Hal ini menunjukan bahwa bahwa kinerja secara signifikan dipengaruhi oleh motivasi intrinsik dan ekstrinsik hal itu terbukti dari nilai sig kedua variabel yang bernilai 0,000 atau dibawah dari margin error yang ditentukan yaitu sebesar $5 \%$ atau 0,050 .

\section{Koefisien Determinasi}

Tabel 2 Koefisien Determinasi

\begin{tabular}{|l|r|r|r|r|r|}
\hline Model & $\mathrm{R}$ & $\mathrm{R}$ Square & \multicolumn{1}{c|}{$\begin{array}{c}\text { Adjusted R } \\
\text { Square }\end{array}$} & $\begin{array}{c}\text { Std. Error of the } \\
\text { Estimate }\end{array}$ & Durbin-Watson \\
\hline 1 & $.790^{\mathrm{a}}$ & .625 & .614 & 3.37187 & 2.208 \\
\hline
\end{tabular}

a. Predictors: (Constant), X2, X1

b. Dependent Variable: $Y$ 
Berdasarkan tabel model summary diatas dapat disimpulkan bahw secara simultan motivasi intrinsic dan ektrinsik berpengaruh terhadap kinerja kader sebesar 0,625 atau $62,50 \%$ artinya motivasi intrinsic dan ekstrinsik mempengaruhi kinerja secara dominan jika dibandingkan dengan variable yang tidak diteliti karena nilai determinasi diatas $50 \%$. .

\section{Pengujian Hipotesis}

Tabel 3 Pengujian Hipotesis

\begin{tabular}{|c|c|c|c|c|c|}
\hline Model & $\begin{array}{l}\text { Sum of } \\
\text { Squares }\end{array}$ & $\mathrm{df}$ & Mean Square & $\mathrm{F}$ & Sig. \\
\hline $\begin{array}{l}\text { Regression } \\
\text { Residual } \\
\text { Total }\end{array}$ & $\begin{array}{r}1306.571 \\
784.495 \\
2091.066\end{array}$ & $\begin{array}{r}2 \\
69 \\
71\end{array}$ & $\begin{array}{r}653.286 \\
11.369\end{array}$ & 57.460 & $.000^{\mathrm{b}}$ \\
\hline
\end{tabular}

a. Dependent Variable: Kinerja Kader

Dari tabel 4.16 diatas terlihat bahwa f hitung 57.460 lebih besar dari pada $F$ tabel 16.876 maka dapat disimpulkan bahwa variabel motivasi intrinsik dan motivasi ekstrinsik memiliki pengaruh yang signifikan terhadap kinerja kader artinya semakin baik motivasi intrinsik dan motivasi ekstrinsik pada diri kader maka akan semakin baik kinerja kader tersebut.

\section{Kesimpulan}

Berdasarkan hasil pembahasan sebelumnya mengenai Pengaruh Motivasi Intrinsik dan Motivasi Ekstrinsik terhadap Kinerja Kader terhadap di Kecamatan Cidahu Kabupaten Kuningan Provinsi Jawa Barat, dapat di ambil kesimpulan sebagai berikut :

1. Motivasi Intrinsik berada pada kategori cukup baik dengan nilai rata-rata ketercapaian skor sebesar 6330 adapun skor harapan sebesar 9720 dan persentase skor keseluruhan mencapai $65,12 \%$ atau berada pada kategori cukup baik.
2. Motivasi Ekstrinsik berada pada kategori cukup baik dengan nilai rata-rata ketercapaian skor sebesar 5026 adapun skor harapan sebesar 7560 dan persentase skor keseluruhan mencapai $66,48 \%$ atau berada pada kategori cukup baik.

3. Kinerja berada pada kategori baik dengan nilai rata-rata ketercapaian skor sebesar 3197 adapun skor harapan sebesar 4680 dan persentase skor keseluruhan mencapai $68,31 \%$ atau berada pada kategori cukup baik.

4. Motivasi Intrinsik memiliki koefisien korelasi sebesar 0,724 dan koefisen determinasi $52,40 \%$.

5. Motivasi Ekstrinsik memiliki koefisien korelasi sebesar 0,603 dan koefisen determinasi $36,40 \%$.

6. Hasil perhitungan Koefisien determinasi ( $R$ Square) yang dinyatakan dalam persentase mengambarkan besarnya kontribusi semua variabel 


\begin{abstract}
bebas yaitu Motivasi Intrinsik $\left(\mathrm{X}_{1}\right)$ dan Motivasi Ekstrinsik $\left(\mathrm{X}_{2}\right)$ dalam menentukan variasi Kinerja(Y) adalah sebesar $62.50 \%$ dan besaran epsilon adalah PyE = 0,375atau sebesar $37,50 \%$ yaitu seperti kompetensi, kesempatan kerja, komunikasi dan kepemimpinan.
\end{abstract}

\section{Saran - Saran}

Berdasarkan hasil pembahasan di bab sebelumnya mengenai Pengaruh Motivasi Intrinsik, Motivasi Ekstrinsik dan Kinerja Kader pada Kecamatan Cidahu Kabupaten Kuningan Provinsi Jawa Barat , dapat di disarankan sebagai berikut :

1. Dalam upaya meningkatkan motivasi intrinsic pegawai sebaiknya pihak kecamatan memberikan program pendidikan dan pelatihan yang dapat menunjang kader dalam melaksanakan pekerjaanya sehingga kemampuan kader akan jauh lebih baik dan akan semkain meningkat motivasi dalam dirinya untuk bekerja lebih maksimal selain itu pengakuan dari pihak lain pun hal ini sangat diperlukan sebaiknya pihak kecamatan memberikan apresiasi atas hasil kerja kader dengan memberikan penghargaan atau cindera mata sebagai upaya mendorong motivasi intrinsic didalam dirinya.

2. Sebaiknya dalam meningkatkan motivasi ekstrinsik pegawai pihak kecamatan sebaiknya melakukan pendekatan dan memberikan pelatihan koordinasi antar kader agar setiap kader dapat bekerjasama dengan lebih baik dan mampu salin tolong menolong dalam memberikan bantuan kepada rekannya yang mengalami kesulitan selain itu pihak kecamatan harus lebih pro aktif dalam melibatkan tokoh masyarakat sehingga motivasi kader akan semakin tinggi dan akan mencapai kinerja yang optimal.

3. Sebaiknya dalam upaya meningkatkan kinerja kader pihak kecamatan perlu meningkatkan intensitas komunikasi dengan kader dan rutin menanyakan kondisi balita yang diawasi oleh para kader tersebut sehingga informasi yang ada atau didapat dilapangan dapat segera terserap selain itu perlu ada upaya pendidikan dand pengajaran kepada para kader agar mampu membuat grafik jumlah balita yang ada diwilayahnyas sehingga akan lebih memudahkan kader dalam melakukan tugasnya dan mencipatakan kinerja kader yang lebih optimal.

4. Motivasi Intrinsik yang ada perlu ditingkatkan karena Motivasi Intrinsik memiliki pengaruh paling dominan sehingga penting bagi manajemen untuk mendorong Motivasi Intrinsik kader dengan berbagai aspek seperti meningkatkan kemampuan kader dalam bekerja dengan memberikan program pelatihan dan pendidikan yang memadai selain itu perlu juga membangun motivasi kader dengan pembaerian penghargaan 
sehingga kader merasa dihargai atas hasil jerih payahnya.

5. Motivasi Ekstrinsik memiliki pengaruh yang kecil dimana Motivasi Ekstrinsik merupakan suatu keharusan bagi karyawan dalam bekerja sehingga Motivasi Ekstrinsik yang sudah ada harus dipertahankan dan ditingkatkan lagi secara berkala dengan meningkatkan reward kepada para kader yang memiliki kinerja baik.

Kedua variable bebas yang diteliti memiliki pengaruh yang positif terhadap kinerja kader maka perlu ada upaya nyata dan berkesinambungan dalam memberikan stimulasi guna meningkatkan kualitas kinerja kader kedepan.

\section{Daftar Pustaka}

Depkes RI (2002). Pedoman Manajemen Peran Serta Masyarakat (Buku Pedoman ARRIF). Jakarta

Depdagri RI (2009). Revitalisasi Posyandu. Jakarta. Depdagri

Dinkes Kuningan (2018). Rencana kegiatan peningkatan program posyandu tahun 2013. Kuningan. Dinkes Kunigan.

Dinas Kesehatan Provinsi Jawa Barat (2006). Profil Kesehatan Provinsi Jawa Barat tahun 2005. Bandung : Dinkes Jabar.

Depkes RI (2007). Laporan Hasil Riset Kesehatan Dasar (Rikesdas) Provinsi Jabar Tahun 2007. Jakarta. Badan Litbangkes. Depkes RI.

Flippo Edwin (1996). Manajemen Personalia, Jilid Indonesia, Edisi keenam, cetakan ketiga. Jakarta : Erlangga.
Gary, Dessler (2003). Manajemen Sumber Daya Manusia, Jakarta : PT. Indeks

Gie, The Liang (2003). Ensikiopedi Administrasi, Jakarta : Gunung Agung

Gibson, James L, John dan James HD (2000). Organisasi Prilaku Struktur dan Proses, Terjemahan Jilid I dan 2 Edisi Kedelapan. Jakarta : Erlangga

Gomes (1999). Manajemen Sumber Daya Manusia. Yogyakarta. Andi ffset.

Handoko (2015). Manajemen Personalia dan Sumber Daya Manusia Edisi 2. Yogyakarta. BPFE Press.

Hasibuan, M. (2005). Manajemen Sumber Daya Manusia. Edisi Revisi. Jakarta : Bumi Aksara.

Heni Djuhaeni, dkk. (2010). Motivasi Kader Meningkatkan Keberhasilan Kegiatan Posyandu.Jurnal ,MKB, Volume 42 No. 4, Tahun 2010.

Herzberg Fredrick (1996). Work and the Nature of man. New York : World Publishing Co.

Indriantoro, Nur dan Supomo, Bambang (2002). Metode Penelitian Bisnis. Yogyakarta : BPFE Yogyakarta.

Kementrian Kesehatan RI bekerja sama dengan Kelompok Kerja Operasional (2011). Pedoman Umum Pengelolaan Posyandu. Jakarta. Kemenkes RI.

Kementrian Kesehatan RI Pusat Promosi Kesehatan (2012). Ayo ke Posyandu Setiap bulan. Jakarta. Kemenkes RI.

Kontesa, M \& Mistuti. (2010). FaktorFaktor Yang Berhubungan Dengan Kinerja Kader Posyandu Di Wilayah Kerja Puskesma Air Dingin Kecematan Koto Tangah Kota Padang. Padang: Jurnal STIKes MERCUBAKTIJAYA Padang. Diakses pada tanggal 26 
Februari2015

dari

http://journal.mercubaktijaya.ac.id/abstra ct-28.html

Kementrian Kesehatan RI (2014). Pedoman Gizi Seimbang. Jakarta : Dirjen Bina Gizi dan KIA.

Luthans, E.A (2012). Organitation Behaviour Sixth Edition. Singapore. McGraw Hill Book Co.

Meria Kontesta, Mistuti, (2013). Jurnal : Faktor-faktor yang berhubungan dengan kinerja kader posyandu di wilayah kerja puskesmas Air dingin Kec. Koto tangah kota padang. Sumatera Barat.

Mangkunegara, Prabu Anwar (2000). Manajemen Sumber Daya Manusia. Bandung : Refika Aditama.

Mastuti, T. (2003). Studi Uji Hubungan Beberapa dengan kelangsungan kader posyandu di kecamatan panjatan kabupaten kulon progo provinsi daerah istimewa Yogyakarta. http://eprint.undip.ac.id/55336/l/1683.pdf.

Dikases januari 2017.

Martoyo, Susilo (2007). Manajemen Sumber Daya Manusia. Yogyakarta : BPFE Press.

Muogbo, Uju S. (2013). The Influence of Motivation on employer Performance ; study of some selected firms in anambra state. Afrrev ijah, 2,2134-152. ISSN: 2225-8590 (PRINT)ISSN 2227-5452 (online).

Mathis and Jackson. (2009). Human Resoucre Management. South-Westren Cengage Learning : USA.

Muhidin, Sambas Ali (2010). Statistika 2 Pengatar untuk Penelitian. Bandung: Karya Adika Utama.

Notoatmodjo, S (2007). Promosi Kesehatan dan IImu Perilaku. Jakarta : Rineka Cipta
Puskesmas Cidahu (2019). Laporan Tahunan Puskesmas Cidahu. Kuingan. Puskesmas Cidahu.

Robbin S.P (2001). Perilaku Organisasi, Kontroversi dan Aplikasi. Jilid (edisi bahasa indonesia). Jakarta : PT Prenhallindo.

Rosse, Eva (2012). Pengaruh Motivasi dan kemampuan kerja terhadap kinerja kader posyandu Lansia di puskesmas lampahan kabupaten bener meriah. Tesis. Universitas Sumatera Utara.

Rivai, V \& Basri (2005). Performance Apprasial. Cetakan I. Jakarta : PT Raja Grafindo Persada.

Siagian, S.P. (1998). Manajemen Sumber Daya Manusia, Cetakan Ketujuh. Jakarta : Bumi Aksara.

Siagian, Sondang P. (2006). Manajemen Sumber Daya Manusia, Edisi I, Cetakan Ketiga Belas. Jakarta : Bumi Aksara.

Suwatno \& Priansa (2011). Manajemen SDM dalam Organisasi Publik dan Bisnis. Bandung : Alfabeta.

Sugiyono (2009). Metode Penelitian Kuantitatif dan Kualitatif. Bandung : Alfabeta.

Sudarsono (2010). Hubungan sikap dan Motivasi terhadap kinerja kader posyandudi wilayah kerjapuskesmas talunkabupaten blitar. https://eprints.uns.ac.id/10234/1/1865011 11201109411.pdf. Diakses 04 pebruari 2017.

(2012). Metode Penelitian Kuantitatif, Kualitatif, dan $R \& D$. Cetakan ke-17. Bandung:Alfabeta

Timple, A. Dale (1999). Manajemen Sumber Daya Manusia Memotivasi Pegawai, Motivation of Personnel. Cetakan keempat. Jakarta : PT Gramedia.

Undang-undang RI No. 36 Tahun 2009, Sistem Kesehatan Nasional. Jakarta : 
ISSN 1412-2936

EISSN 2549-7308

http://www.jdih.kemenkeu.go.id/fulltext/2 009/36TAHUN2009UU.htm. Diakses 02 Pebruari 2017.

Zulkifli (2003). Posyandu dan kader kesehatan. Sumatera Utara.

http://library.usu.ac.id. Diakses 02 pebruari 2017

Wayne R., Pacedon F. Faules. (2005). Komunikasi organisasi strategi meningkatkan kinerja perusahaan. Dalam Timpe. 2003(Ed.), Faktor-Faktor Yang Mempengaruhi Kinerja. Bandung : Erlangga 